\title{
Impact of large-scale organic conversion on food production and food security in two Indian states, Tamil Nadu and Madhya Pradesh
}

\author{
P. Panneerselvam ${ }^{1 *}$, John Erik Hermansen ${ }^{1}$, Niels Halberg ${ }^{2}$ and P. Murali Arthanari ${ }^{3}$ \\ ${ }^{1}$ Department of Agroecology, Faculty of Science and Technology, Aarhus University, Blichers Allé, PO Box 50, \\ DK-8830 Tjele, Denmark. \\ ${ }^{2}$ International Centre for Research in Organic Food Systems (ICROFS), Blichers Allé, PO Box 50, DK-8830 Tjele, \\ Denmark. \\ ${ }^{3}$ Department of Agronomy, Tamil Nadu Agricultural University, Coimbatore, India. \\ ${ }^{*}$ Corresponding author: panneerkvt@gmail.com
}

\begin{abstract}
The millions of food insecure people in India are not solely due to inadequate food production, but also because some people are simply too poor to buy food. This study assessed how a large-scale conversion from conventional to organic production would impact on the economics of marginal and small farmers in Tamil Nadu and Madhya Pradesh, and on the total food production in these states. This study also considered a situation where fertilizer subsidies would be discontinued, with farmers having to carry the full cost of fertilizer. Results show that conversion to organic improved the economic situation of farmers although food production was reduced by $3-5 \%$ in the organic situation. Thus, the estimated economic values were higher in the organic system (5-40\% in fertilizer subsidy scenario and $22-132 \%$ in no fertilizer subsidy scenario) than in the conventional system, whereas the total state-level food productions were lowered by $3-5 \%$ in the organic compared to the conventional system. Food production was higher when rainfed, and lower in the irrigated situation in the large-scale organic scenario. Although the study addresses short-term perspectives of large-scale conversion to organic farming, more research is needed to understand the long-term impact of organic conversion on food production, nutrient supply, food security and poverty reduction.
\end{abstract}

Key words: organic farming, small farmers, food production, food security

\section{Introduction}

Green revolution technologies increased food production and helped India to achieve self-sufficiency in the $1980 \mathrm{~s}^{1}$. However, India is still home to 231 million undernourished people with a majority of these (175 million) living in rural areas ${ }^{2}$. This highlights the fact that the green revolution did not entirely address the issues faced by a significant section of rural India which comprises mainly marginal and small farmers. In India, $81 \%$ of farms are $<2$ ha and make up $38 \%$ of the total cultivated area $^{3}$.

The FAO conference on organic agriculture and food security in May 2007 concluded that organic agriculture has the potential to improve the food security in developing countries, particularly for small farmers ${ }^{4}$.
Organic agriculture includes both certified and noncertified food systems. Organic agriculture may improve the local food security through the production of a diverse range of products at a lower input cost than in conventional farming ${ }^{5}$, thus alleviating the poverty of smallholders. Organic agriculture may also have a number of environmental benefits like improved soil structure, increase in soil organic matter content ${ }^{6,7}$ and larger biodiversity ${ }^{8,9}$, even though this is mostly documented in temperate regions. Under low-input conditions such as in East Africa, organic agriculture - mostly noncertified - has been found by a large number of NGOs to improve yields and food security ${ }^{10}$. However, organic farming has been found to result in lower crop yields ${ }^{11,12}$, especially in high-yielding areas, and there is a challenge in managing the nitrogen availability in organic systems ${ }^{11}$. 
Only a few have studied the large-scale conversion of organic farming and its possible impacts on food production and food security. Organic conversion would not have a severe impact on global food supply, but would rather help to improve local food availability and food security in developing countries, particularly subSaharan Africa ${ }^{13}$. The results of another study show that organic methods could produce enough food on a global per capita basis to sustain the current or a larger population without increasing the land area under cultivation ${ }^{14}$. These modeling studies considered the impact of organic agriculture on global food supply and world food security. However, there is lack of countryspecific modeling of large-scale organic conversion on food security. Hence, this study was to assess the economic situation of marginal and small farm types, and state-level food production in the large-scale organic scenario in two states of India-Tamil Nadu and Madhya Pradesh.

\section{Materials and Methods}

This section is divided into five subsections: the first subsection presents the land-use pattern and socio-economic situations in the studied states before large-scale conversion, the second subsection describes the land-use changes and yield ratio for large-scale organic conversion, the third subsection shows the data sources and secondary data collection at state level, the fourth subsection describes the method of calculation for assessing the economic situation, and calculation of the state-level food production in the organic scenario is presented in the fifth subsection.

\section{Land use and socio-economic situation before large-scale conversion}

Two states in India were considered in this study-Tamil Nadu and Madhya Pradesh, which represent different but typical challenging situations of a high proportion of resource-poor smallholder farmers dependent on rainfed agriculture. Moreover, there are experiences with organic agriculture in these two states, which formed a basis for household-level surveys. In order to study a hypothetical situation where all the marginal and small farm types would convert their production to organic farming, it was necessary to create a simulation of a regional status by upscaling the significantly relevant factors. The first part of this study at the household level ${ }^{15}$ conducted in three states of India in order to represent three very different situations in terms of agro-ecological conditions, farming system, market access and activities of NGOs promoting organic farming. The states chosen for household study were Uttarakhand, Madhya Pradesh and Tamil Nadu, respectively from north, central and southern parts of India. However, Uttarakhand, a new state, was left out for the up-scaling due to lack of secondary data. In Tamil Nadu, the Center for Indian Knowledge system, an NGOs promotes organic farming among small and marginal farmers to improve their food security. The NGO provides training to the farmers on organic farming and, to some extent, interest free credit. Also, the NGO educates the farmers to use farm resources to manage soil fertility and pests and diseases. In Madhya Pradesh, BioRe India, a private company, promotes organic cotton production. BioRe provides the associated farmers with training and technical advice on organic cotton production and purchases the cotton with a $20 \%$ price premium on actual market rates. The company operates an internal control system and arranges for external organic certification by an internationally accredited agency. Costs for extension, certification and for the organic price premium are recovered by selling the certified organic fiber at a higher price in international markets. The up-scaling of household study is justifiable because small and marginal holders represent more than $70 \%$ of the total farm holding in Madhya Pradesh and 90\% in Tamil Nadu (Tables 1 and 2).

In Tamil Nadu, marginal and small farms accounted for $90 \%$ of the total farm holdings, contributing $62 \%$ of the total food grain production of the state (Table 1), whereas in Madhya Pradesh, marginal and smallholdings constitute $70 \%$ of the cultivated land area, producing $30 \%$ of the total food grain output (Table 2). The share of pulses to the total food grain basket is higher in Madhya Pradesh, sharing $27 \%$ of the food grain area and $17 \%$ of the food grain production. Rice is the major crop in Tamil $\mathrm{Nadu}$, whereas wheat and rice are the major crops in Madhya Pradesh. Each marginal and small farm cultivates an average of 0.48 ha in Tamil Nadu and 0.87 ha in Madhya Pradesh. In India, farm classification is based on the landholding size, and a household possessing $<1$ ha of land is classified as a marginal holding, 1-2 ha is a smallholding, 2-4ha is semi-medium, $4-10$ ha is medium and large holding is 10 ha and above.

Typically, marginal and small farms mainly borrow from private lenders to meet the cost of fertilizers and pesticides, and hence they are highly vulnerable to indebtedness because of the high risk of crop failure due to climatic variability. Private lenders are the primary source of loans for marginal farmers both in Tamil Nadu and Madhya Pradesh, whereas government institutions and private lenders are the primary source of loans for the small farmers (Table 3).

\section{Yield ratios and land-use changes in large-scale organic scenario}

We derived yield ratios for organic and conventional farms from two studies ${ }^{16,17}$. The yield differences between the organic and conventional systems from these two studies are presented in Table 4. The ratios of crop yield and variable cost between the organic and 
Table 1. Land use, crop production and number of holdings under different farm types in Tamil Nadu.

\begin{tabular}{|c|c|c|c|c|c|c|}
\hline & \multicolumn{3}{|c|}{ All farm types } & \multicolumn{2}{|c|}{$\begin{array}{l}\text { Marginal and small } \\
\text { farm types }\end{array}$} & \multirow[b]{2}{*}{$\begin{array}{l}\% \text { share of marginal and } \\
\text { small farm types in area }\end{array}$} \\
\hline & $\begin{array}{c}\text { Area } \\
(1000 \mathrm{ha})\end{array}$ & $\begin{array}{l}\text { Percent under } \\
\text { irrigation }\end{array}$ & $\begin{array}{l}\text { Production } \\
(1000 t)\end{array}$ & $\begin{array}{c}\text { Area } \\
(\mathbf{1 0 0 0 h a )}\end{array}$ & $\begin{array}{l}\text { Production } \\
(1000 t)\end{array}$ & \\
\hline Cereals (A) & 2581 & 54 & 7056 & 1626 & 4372 & 63 \\
\hline Rice & 1808 & 93 & 5649 & 1175 & 3672 & 65 \\
\hline Sorghum & 334 & 6 & 313 & 190 & 178 & 57 \\
\hline Maize & 194 & 40 & 727 & 80 & 299 & 41 \\
\hline Pulses (B) & 559 & 4 & 237 & 307 & 133 & 55 \\
\hline Food grains $(\mathrm{A}+\mathrm{B})$ & 3140 & 58 & 7294 & 1947 & 4506 & 62 \\
\hline Oilseeds (C) & 643 & & 1163 & 399 & 714 & 62 \\
\hline Other crops (D) & 2035 & & & 1080 & & \\
\hline $\begin{array}{l}\text { Total cropped area } \\
\qquad(\mathrm{A}+\mathrm{B}+\mathrm{C}+\mathrm{D})^{I}\end{array}$ & 5819 & & & 3426 & & 59 \\
\hline Irrigated & 3515 & & & 2139 & & 61 \\
\hline Rainfed & 2304 & & & 1286 & & 56 \\
\hline Total no. of holdings & $7,858,887$ & & & $7,072,155$ & & 90 \\
\hline Average area/holding (ha) & 0.74 & & & 0.48 & & \\
\hline
\end{tabular}

1 This represents the total area sown in a year, i.e., the area counted as many times as there are sowings in a year.

Table 2. Land use, crop production and number of holdings under different farm types in Madhya Pradesh.

\begin{tabular}{|c|c|c|c|c|c|c|}
\hline & \multicolumn{3}{|c|}{ All farm types } & \multicolumn{2}{|c|}{$\begin{array}{l}\text { Marginal and small farm } \\
\text { types }\end{array}$} & \multirow[b]{2}{*}{$\begin{array}{l}\% \text { share of marginal } \\
\text { and small farm types }\end{array}$} \\
\hline & $\begin{array}{c}\text { Area } \\
(1000 \text { ha })\end{array}$ & $\begin{array}{l}\text { Percent under } \\
\text { irrigation }\end{array}$ & $\begin{array}{l}\text { Production } \\
(1000 \text { t) }\end{array}$ & $\begin{array}{c}\text { Area } \\
(1000 \text { ha })\end{array}$ & $\begin{array}{c}\text { Production } \\
(1000 t)\end{array}$ & \\
\hline Cereals (A) & 7270 & & 10,358 & 2250 & 3223 & 31 \\
\hline Rice & 1660 & 14 & 1527 & 634 & 583 & 38 \\
\hline Wheat & 3990 & 82 & 6731 & 1114 & 1880 & 28 \\
\hline Maize & 860 & & 1064 & 275 & 341 & 32 \\
\hline Pulses (B) & 3250 & & 2568 & 815 & 670 & 26 \\
\hline Chickpea & 2460 & 50 & 2061 & 605 & 507 & 25 \\
\hline Food grains $(\mathrm{A}+\mathrm{B})$ & 10,520 & & 12,927 & 3064 & 3894 & 30 \\
\hline Oilseeds (C) & 5650 & & 5634 & 1327 & 1367 & 24 \\
\hline Soybean & 4760 & & 4693 & 1057 & 1042 & 22 \\
\hline Cotton (D) & 640 & 40 & 829 & 164 & 212 & 25 \\
\hline Others (E) & 1113 & & & 314 & & \\
\hline $\begin{array}{l}\text { Total cropped area } \\
\qquad(\mathrm{A}+\mathrm{B}+\mathrm{C}+\mathrm{D}+\mathrm{E})^{I}\end{array}$ & 17,923 & & & 4869 & & 27 \\
\hline Irrigated & 4266 & & & 1125 & & 26 \\
\hline Rainfed & 13,657 & & & 3743 & & 27 \\
\hline Total no. of holdings & $7,472,000$ & & & $5,075,000$ & & 70 \\
\hline Average area/holding (ha) & 2.00 & & & 0.87 & & \\
\hline
\end{tabular}

1 This represents the total area sown in a year, i.e., the area counted as many times as there are sowings in a year.

conventional productions were calculated and are presented in Table 5. The yield ratio is the proportion of organic to non-organic yields reported by the studies. For example, the yield ratio of 0.80 means organic yield is $80 \%$ of the conventional yield obtained from the same crop from a given area. Similarly, the variable cost ratio is the ratio of organic to non-organic cost incurred for producing a given quantity of produce. Relative land use is the proportion of the area of a particular crop in an organic system relative to the non-organic system. In the up-scaling process, a number of assumptions of crops grown was made. The assumption on land-use changes has been performed based on the crop yield, the external input, nitrogen fixation, nutritional impacts and 
Table 3. Indebtedness and source of loan by farm types in Tamil Nadu and Madhya Pradesh.

\begin{tabular}{|c|c|c|c|c|c|c|}
\hline & \multicolumn{3}{|c|}{ Tamil Nadu } & \multicolumn{3}{|c|}{ Madhya Pradesh } \\
\hline & Marginal & Small & Others & Marginal & Small & Others \\
\hline Share of farms in total indebted farm households $(\%)$ & 72.7 & 15.4 & 11.9 & 33.0 & 27.0 & 40.0 \\
\hline \multicolumn{7}{|l|}{ Source of loan $(\%)$} \\
\hline Government and cooperative societies & 18.7 & 25.4 & 23.0 & 8.43 & 14.5 & 26.4 \\
\hline Banks & 15.3 & 36.1 & 51.1 & 21.3 & 38.2 & 41.4 \\
\hline Moneylenders & 56.4 & 29.9 & 19.7 & 41.5 & 21.2 & 17.3 \\
\hline Traders & 0.9 & 0.4 & 0.3 & 9.6 & 14.2 & 5.5 \\
\hline Friends & 6.8 & 7.2 & 1.7 & 16.8 & 10.4 & 8.7 \\
\hline Others & 1.8 & 1 & 3.9 & 2.2 & 1.5 & 0.5 \\
\hline All & 100 & 100 & 100 & 100 & 100 & 100 \\
\hline
\end{tabular}

Source: Adopted from the situation assessment survey of farmers in India, by $\mathrm{NSS}^{26}$.

Table 4. Average yield $\left(\mathrm{kg} \mathrm{ha}^{-1}\right)$ in organic and conventional systems (from Eyhorn et al. ${ }^{17}$ and Panneerselvam et al. ${ }^{41}$ ).

\begin{tabular}{lcclrr}
\hline & \multicolumn{2}{c}{ Panneerselvam et al. ${ }^{\mathbf{4 1 1}}$} & & \multicolumn{2}{c}{ Eyhorn et al. ${ }^{\mathbf{1 7 2}}$} \\
\cline { 2 - 4 } & Organic & Conventional & & Organic & Conventional \\
\hline Cotton irrigated & 1322 & 1694 & Maize & 1373 & 1287 \\
Cotton rainfed & 1044 & 1187 & Sorghum & 424 & 430 \\
Wheat & 1250 & 2080 & Pigeon pea & 1022 & 803 \\
Rice & 3392 & 4270 & Soybean & 870 \\
Peanut & 1246 & 1432 & & & \\
\hline
\end{tabular}

1 Average of 40 farms each in organic and conventional.

2 Average of 60 farms each in organic and conventional.

greenhouse gas emission. Detailed assumptions for the organic scenario are presented in Table 5. In general, the major shift in the cropping pattern toward rice and wheat in India has resulted in a lower consumption of pulses, from $42 \mathrm{~g}$ per capita per day in 1990 (72 $\mathrm{g}$ in 1956) to $33 \mathrm{~g}$ in $2005^{18}$. This has incidentally resulted in more than $50 \%$ of the Indian population having a protein calorie deficiency ${ }^{19}$. Moreover, rice emits more greenhouse gas than peas or pulses ${ }^{20}$, so increasing the area under legumes has potential advantages in terms of reducing malnutrition, greenhouse gas emissions and improving soil fertility.

In the present scenarios, the relative land use was determined based on the distribution and performance of the crops under organic systems from household surveys ${ }^{16}$ showing more pulses grown and homeconsumed in organic households. This was supported by other studies that suggest integration of legumes in the cropping systems in organic scenarios for nutrient management. Moreover, the Tamil Nadu State Agricultural Department recommended an alternative cropping pattern for some rice-growing areas, suggesting that it could be replaced by maize or pulses particularly in rainfed situations with, or under uncertainty in, water release from reservoirs ${ }^{21}$. A high number of farmers in Kerala reduced their rice area due to deterioration of soil health, poor nutrient use efficiency and a build-up of pests and diseases, and converted to more profitable crops ${ }^{22}$. Another study also suggests that crop diversification of maize, pulses (green gram, pigeon pea and black gram) and ground nut performs better in rainfed rice areas, and suggests that the area under rainfed rice could be replaced by maize or pulses to increase the income of the farmers ${ }^{23}$.

\section{Data collection at the state level}

The secondary data on land size, percentage of area under irrigation and number of holdings were derived from the state statistics ${ }^{3,24-26}$. The area of each crop at the state level was derived from 'Agricultural statistics at a glance ${ }^{24}$. The area under each crop for marginal and small farms was extracted. Owing to the lack of accurate data for crop yields across the farm types, the yields were assumed equal for all farm types, although small farms could be expected to produce higher yields than large farms. Production in the conventional system from marginal and small farms was set as baseline production. Variable costs in conventional farming included purchase of seeds, fertilizers, manures and chemicals. Labor cost was not included in the calculation because it was difficult to obtain trustworthy data. An earlier comparative study omitted labor costs from the calculation of the 
Table 5. Ratio of crop yield, variable cost and land use in an organic scenario compared to the baseline (conventional).

\begin{tabular}{|c|c|c|c|c|}
\hline & \multirow[b]{2}{*}{ Yield ratio } & \multirow[b]{2}{*}{ Variable cost ratio } & \multicolumn{2}{|c|}{$\begin{array}{l}\text { Relative land occupation of each crop } \\
\text { following adjustment of the cropping pattern } \\
\text { in the organic scenario }\end{array}$} \\
\hline & & & Tamil Nadu & Madhya Pradesh \\
\hline Rice & 0.80 & 0.67 & 0.50 & 0.50 \\
\hline Wheat & 0.60 & 0.36 & & 0.50 \\
\hline Sorghum & 1.1 & 0.88 & 0.50 & 1.00 \\
\hline Pearl millet & 1.1 & 0.88 & 0.50 & 2.81 \\
\hline Maize & $1.1(0.94)$ & 0.92 & 5.27 & 1.08 \\
\hline Finger millet & 1.1 & 0.88 & 0.50 & \\
\hline Other cereals & 1.1 & 0.88 & 0.47 & \\
\hline Pigeon pea & 0.92 & 0.73 & 4.75 & 1.47 \\
\hline Green gram & 0.92 & 0.73 & 3.46 & \\
\hline Black gram & 0.92 & 0.73 & 1.00 & \\
\hline Chick pea & 0.92 & 0.73 & & 1.92 \\
\hline Lentil & 0.92 & 0.73 & & 1.00 \\
\hline Other pulses & 0.92 & 0.73 & 1.04 & \\
\hline Peanut & $0.92(0.87)$ & 0.66 & 1.40 & 4.14 \\
\hline Sesame & $0.92(0.87)$ & 0.66 & 0.85 & \\
\hline Soybean & 0.95 & 0.94 & & 1.02 \\
\hline Mustard & 0.92 & 0.66 & & 1.00 \\
\hline Cotton & $0.88(0.78)$ & 0.36 & & 0.50 \\
\hline
\end{tabular}

Note: The values in ( ) are the ratios for the irrigated situation of the respective crops. All of the other ratios are for the rainfed situation, except rice and wheat.

Relative land use: Value 1 indicates no change in land use in the organic situation for a particular crop. Value 0.5 indicates a $50 \%$ area reduction under particular crops in the organic situation. Value 2 indicates a $100 \%$ area increase in the organic situation for a particular crop.

net revenues ${ }^{27}$ since very often in developing countries family labor has little opportunity for income ${ }^{13,28,29}$. The household survey ${ }^{16}$ attempted to study labor use in farming activities on an individual farm basis when pretesting the questionnaire. However, it was not possible to obtain sufficiently precise numbers due to the use of family labor for most of the farming activities and a highly irregular nature of input, e.g., varying between 2 and $9 \mathrm{hday}^{-1}$ depending on need. Other studies have reported no differences in labor input between the organic and conventional farms in India ${ }^{17}$ and suggest that smallholders have adequate labor force for farming organically $^{30}$.

\section{Calculation of the parameters for assessing the economic situation in the organic scenario}

The economic condition of the farmers was estimated in two situations: first by subtracting the variable cost (including interest at different rates) from the crop value, and second by subtracting the total costs (variable cost plus cost of fertilizer subsidy) from the crop value. The interest rate for the costs incurred for the inputs was included in the assessment. Variable costs include interest rates of 15 and $30 \%$ per annum, respectively, for loans obtained from the government and private moneylenders $^{31}$. Also, a hypothetical situation of the government withdrawing the fertilizer subsidies was considered - as happened in Ethiopia where fertilizer subsidies were withdrawn from $1998^{32}$. In this situation, the farmers have to carry the cost of the fertilizer subsidies, because the cost of this subsidy is added to the input costs. The fertilizer subsidies were derived from the secondary data for the marginal and the smallholders in Tamil Nadu and Madhya Pradesh ${ }^{33}$ and calculated for the unit area. A sensitivity analysis was performed by assuming different premium prices of the organic sales of 10 or $20 \%$. This was based on the price premium of $10 \%$ found for the non-certified organic products in Tamil Nadu and for Madhya Pradesh a price premium of $20 \%$ was found for the certified organic products ${ }^{16}$. It is acknowledged that the up-scaling does not take into account the longterm impact of organic agriculture and costs of certification and training (often covered by the NGOs). However, the up-scaling process has the advantage of integrating some hypothetical assumptions of different issues and their impact on food production and income.

\section{Calculation of state-level food production in the organic scenario}

The methodological framework for the calculation of food production is presented in Fig. 1. The areas of marginal and small farms were extracted from the total 


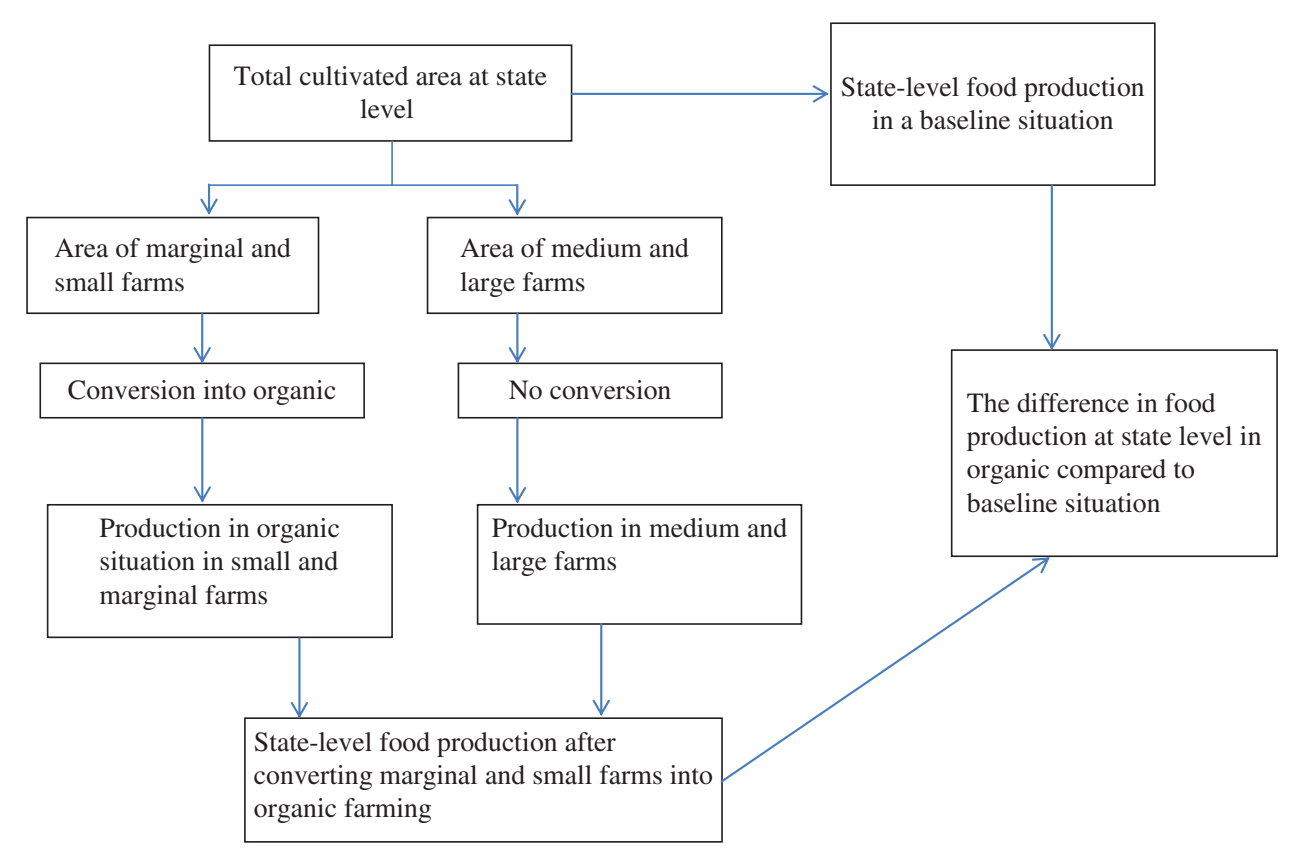

Figure 1. Methodological framework of the up-scaling process.

cultivated area at the state level. The areas under marginal and small farms were converted to organic by applying the hypothetical assumptions mentioned above. The production from these converted areas is labeled as Organic MS production. The productions were calculated separately for the rainfed and the irrigated areas occupied by the marginal and small farms. Production from the medium and the large farms (not converted to organic) was added to the Organic MS production to obtain Organic production at the state level. Production from the marginal and the small farms under the conventional system of production is Baseline MS production. Production from all of the farm types from the conventional systems is called Baseline production at the state level.

\section{Results}

\section{Estimated economic value of the farm holdings}

The estimated crop value in the organic scenario was lower $(6-8 \%)$ than in the baseline scenario when no price premium was assumed, both in Tamil Nadu and Madhya Pradesh (Table 6). However, the estimated gross margin was higher in organic than in baseline both in Tamil Nadu and Madhya Pradesh, even at no price premium (Table 6). This was due to the $30 \%$ input cost reduction in organic systems. The variation in gross margin between the organic and the baseline increased with increasing price premium for organic products and, though less markedly, increased interest rate on the input cost. The difference in gross margin increased with increasing interest rate on loans which was due to the higher input cost in the conventional system reducing their gross margin. The gross margin was Rs. 5269 for the baseline compared with Rs. 7200 for the organic scenario in Tamil Nadu, when given a $10 \%$ price premium for noncertified organic products and organic farmers receiving interest-free credits from NGOs, in contrast to conventional farmers receiving credit at $30 \%$ interest as observed in the organic project area ${ }^{15}$. The gross margin was Rs. 5814 for the baseline scenario compared with Rs. 7912 for the organic in Madhya Pradesh. This means about $36 \%$ increase of the gross margin in the organic scenario over the baseline.

The variation in the gross margin between the organic and the conventional was much wider in the hypothetical situation of no fertilizer subsidy, thus the organic had a higher gross margin than the conventional in Tamil Nadu, at 80,106 and $132 \%$ with a 0,10 and $20 \%$ price premium, respectively (Table 7). Similarly, the gross margin was 43, 63 and $84 \%$ higher in the organic systems at a 0,10 and $20 \%$ price premium in Madhya Pradesh. These were due to higher production costs in the conventional system due to additional costs of fertilizer subsidy in the input cost, and a price premium for the organic products. In Tamil Nadu, under the no fertilizer subsidy scenario, organic farms had higher gross margin, 98 and $124 \%$ increase over the baseline at 0 and $10 \%$ premium price (for the organic product), respectively, whereas in Madhya Pradesh, the organic farms had a higher gross margin and 57 and $78 \%$ increase over the baseline at 0 and $10 \%$ premium price, respectively. Conventional farmers in Tamil Nadu were more affected than those in Madhya Pradesh because of their more extensive use of fertilizer and higher fertilizer subsidy per holding. 
Table 6. Estimated economic key figures in the baseline and the organic scenarios from the marginal and the small farms (Indian rupees/holding per year).

\begin{tabular}{|c|c|c|c|c|c|c|c|}
\hline & & \multicolumn{3}{|c|}{ Tamil Nadu (area 0.48 ha) } & \multicolumn{3}{|c|}{ Madhya Pradesh (area 0.87 ha) } \\
\hline & & Baseline & Organic & Difference $(\%)^{I}$ & Baseline & Organic & Difference $(\%)^{I}$ \\
\hline \multirow[t]{3}{*}{ Crop value at 0,10 and $20 \%$ price premium } & 0 & 8829 & 8295 & -6 & 10,063 & 9186 & -8 \\
\hline & 10 & 8829 & 9124 & 3 & 10,063 & 10,104 & 0.4 \\
\hline & 20 & 8829 & 9954 & 13 & 10,063 & 11,023 & 10 \\
\hline \multicolumn{8}{|l|}{ Variable costs } \\
\hline \multirow[t]{3}{*}{ Input cost plus 0,15 and $30 \%$ interest rate } & 0 & 2738 & 1924 & -30 & 3268 & 2192 & -33 \\
\hline & 15 & 3148 & 2212 & -30 & 3758 & 2521 & -33 \\
\hline & 30 & 3559 & 2501 & -30 & 4248 & 2849 & -33 \\
\hline \multicolumn{8}{|l|}{ Gross margins } \\
\hline \multirow{3}{*}{$\begin{array}{l}\text { Gross margin at } 0,10 \text { and } 20 \% \text { price premium } \\
\text { at } 0 \% \text { interest rate on input cost }\end{array}$} & 0 & 6091 & 6371 & 5 & 6795 & 6994 & 3 \\
\hline & 10 & 6091 & 7200 & 18 & 6795 & 7912 & 16 \\
\hline & 20 & 6091 & 8030 & 32 & 6795 & 8831 & 30 \\
\hline \multirow{3}{*}{$\begin{array}{l}\text { Gross margin at } 0,10 \text { and } 20 \% \text { price premium } \\
\text { at } 15 \% \text { interest rate on input cost }\end{array}$} & 0 & 5680 & 6082 & 7 & 6305 & 6665 & 6 \\
\hline & 10 & 5680 & 6912 & 22 & 6305 & 7584 & 20 \\
\hline & 20 & 5680 & 7741 & 36 & 6305 & 8502 & 35 \\
\hline \multirow{3}{*}{$\begin{array}{l}\text { Gross margin at } 0,10 \text { and } 20 \% \text { price premium } \\
\text { at } 30 \% \text { interest rate on input cost }\end{array}$} & 0 & 5269 & 5794 & 10 & 5814 & 6336 & 9 \\
\hline & 10 & 5269 & 6623 & 25 & 5814 & 7255 & 25 \\
\hline & 20 & 5269 & 7453 & 41 & 5814 & 8173 & 40 \\
\hline
\end{tabular}

1 Difference in the percentage in organic compared to the baseline.

Note: crop value $=$ yield $\times$ price, Gross margin $=$ crop value - variable cost.

Table 7. Estimated economic key figures in the baseline (assuming the inclusion of fertilizer subsidy in the variable costs) and the organic scenarios (Indian rupees/holding per year).

\begin{tabular}{|c|c|c|c|c|c|c|c|}
\hline & & \multicolumn{3}{|c|}{ Tamil Nadu (area 0.48 ha) } & \multicolumn{3}{|c|}{ Madhya Pradesh (area 0.87 ha) } \\
\hline & & Baseline & Organic & Difference $(\%)^{I}$ & Baseline & Organic & Difference $(\%)^{I}$ \\
\hline \multirow{3}{*}{$\begin{array}{l}\text { Total cost: Input cost plus cost of fertilizer } \\
\text { subsidy plus } 0 / 15 / 30 \% \text { interest }\end{array}$} & 0 & 4325 & 1924 & -55 & 4323 & 2192 & -49 \\
\hline & 15 & 4973 & 2212 & -55 & 4971 & 2520 & -49 \\
\hline & 30 & 5622 & 2501 & -55 & 5619 & 2849 & -49 \\
\hline \multicolumn{8}{|l|}{ Gross margin } \\
\hline \multirow{3}{*}{$\begin{array}{l}\text { Gross margin at } 0,10 \text { and } 20 \% \text { price } \\
\text { premium at no interest on total cost }\end{array}$} & 0 & 4504 & 6371 & 41 & 5740 & 6994 & 22 \\
\hline & 10 & 4504 & 7200 & 60 & 5740 & 7912 & 38 \\
\hline & 20 & 4504 & 8030 & 78 & 5740 & 8831 & 54 \\
\hline \multirow{3}{*}{$\begin{array}{l}\text { Gross margin at } 0,10 \text { and } 20 \% \text { price } \\
\text { premium at } 15 \% \text { interest rate on total cost }\end{array}$} & 0 & 3855 & 6082 & 58 & 5091 & 6665 & 31 \\
\hline & 10 & 3855 & 6912 & 80 & 5091 & 7583 & 49 \\
\hline & 20 & 3855 & 7741 & 100 & 5091 & 8502 & 67 \\
\hline \multirow{3}{*}{$\begin{array}{l}\text { Gross margin at } 0,10 \text { and } 20 \% \text { price } \\
\text { premium at } 30 \% \text { interest rate on total cost }\end{array}$} & 0 & 3206 & 5793 & 81 & 4443 & 6336 & 42 \\
\hline & 10 & 3206 & 6623 & 106 & 4443 & 7255 & 63 \\
\hline & 20 & 3206 & 7453 & 132 & 4443 & 8173 & 84 \\
\hline
\end{tabular}

1 Difference in the percentage in the organic compared to the baseline.

Note: crop value $=$ yield $\times$ price, Gross margin $=$ crop value - variable cost.

\section{Estimated production after large-scale conversion of marginal and small farm types}

Marginal and small farms cultivate 3.4 million ha $(59 \%$ of the area of all of the farm types) in Tamil Nadu and 4.8 million ha (27\% of the area of all of the farm types) in Madhya Pradesh. Conversion of these marginal and small farms into organic farming reduced food production at the state level, $5 \%$ in Tamil Nadu and 3\% in
Madhya Pradesh over the baseline (Table 8). The conversion of the rainfed areas exclusively was beneficial by producing 13 and $4 \%$ more food from these areas in Tamil Nadu and Madhya Pradesh, respectively, compared to their rainfed baseline, whereas the organic conversion of the irrigated areas had a negative impact on food production. Owing to the assumed land-use changes, the production of pulses and oilseeds was found to be consistently higher in the organic scenario than the 


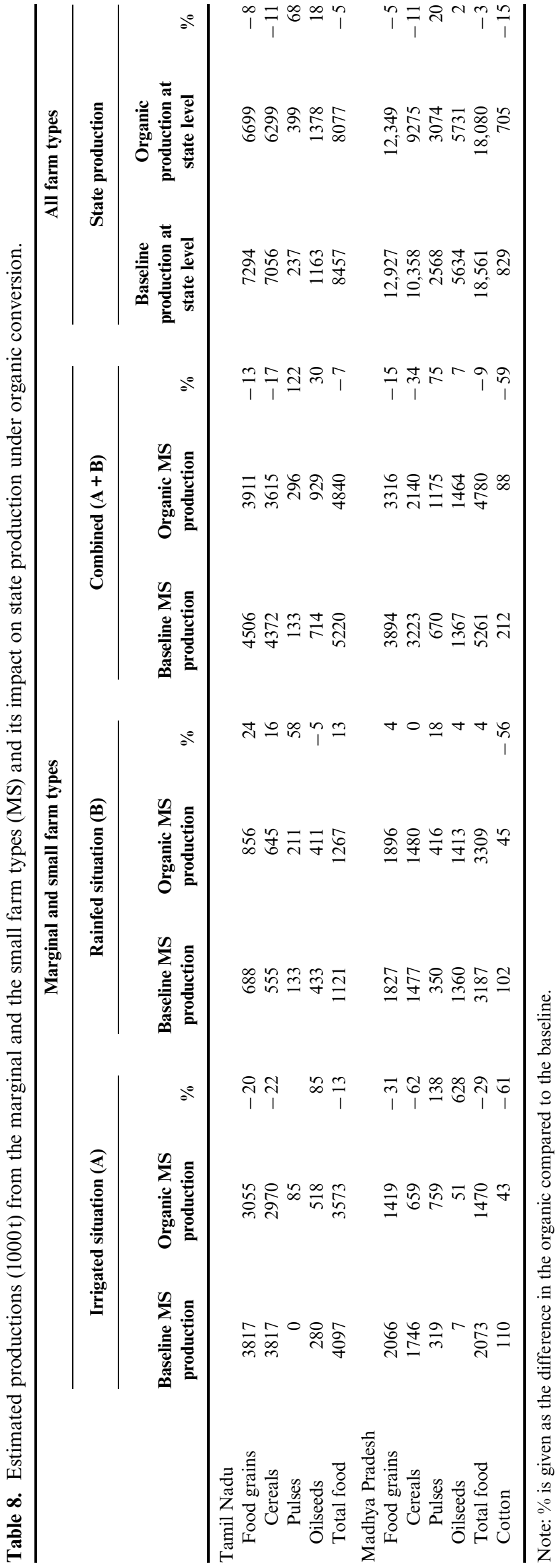

baseline scenario. In Tamil Nadu, the estimated pulse and oilseed productions were, respectively, 68 and $18 \%$ higher in the organic than the baseline scenario, whereas in Madhya Pradesh the rise was 20 and 2\%, respectively.

\section{Discussion}

Most of the households in the two states of India are marginal and small farms cultivating $<2$ ha and a large proportion of the farms are indebted. They need low-cost technology that uses on-farm resources to lever themselves out of the vicious cycle of poverty and food insecurity. This modeling study showed that large-scale conversion may have both positive and negative impacts on food security. Marginal and small farms-which constitute 90 and $70 \%$ (Tables 1 and 2) of the total farm holdings in Tamil Nadu and Madhya Pradesh, respectively - can potentially increase the gross margin (mainly by reducing production costs) and avoid the risk of debt by converting to organic. But such a large-scale conversion could also reduce food production by approximately $5 \%$ at the state level, if the organic yields are not improved.

The smallholder farmers can increase their income even without a price premium if they receive proper training and technical support to manage soil and pests ${ }^{15}$. Systematic training and extension in agro-ecological practices - which is not only supported by the NGOs but also by the state and the central governments - could increase nutrient management and crop yields, for example, by supporting organic fertilization parallel to the subsidies to chemical fertilizer use. Building improved soil fertility through agro-ecological practices could also render organic farms more resilient to climatic instability $^{34}$ and to changes in government policy, such as a discontinuation of fertilizer subsidy. In such a situation, the conventional system of production would be much more affected, assuming that the cost of the fertilizer subsidy would be carried by the farmers. The present level and the mechanism of the fertilizer subsidies masks the high costs of conventional production, and organic production would be even more competitive if such subsidies were not only tied to the fertilizer but also to organic manure and other agro-ecological soil fertility management practices. This is not just a theory, but is practiced in the Philippines under the Organic Fertilizer Production Project supported by the Bureau of Soils and Water Management (BSWM) to assist the national rice and corn program ${ }^{35}$. The Philippine government has supported this project by establishing 64 biological nitrogen fertilizer production units, about 2700 community-based composting facilities and 26,713 bags of annual production $(50 \mathrm{~kg}$ per bag) of organic fertilizers. Similarly, a study from India found that small farms improved their economic and ecological indicators in a scenario with a policy to support organic agricultural 
practices compared to a policy that continues to support market based, synthetic inputs for cultivation ${ }^{36}$.

Certification costs and conversion costs were not included in this study. It may not be realistic to assume price premiums for all of the organic crops sold under a large-scale conversion scenario, since most produce will be home-consumed or sold locally. Thus, this upscaling model included an organic scenario with no price premium (for non-certified organic products) and therefore, will not require costs for conversion and certification, besides the basic training in agro-ecological practices. Also, it is difficult to calculate the cost for conversion on an individual basis for the small and the marginal farms in India as most often the NGOs or companies promoting organic organize free training, extension and help certification on a group basis. Examples are, in the case of Tamil Nadu, the Center for Indian Knowledge systems ${ }^{15}$ and, in the case of Madhya Pradesh, a private company, BioRe $^{15}$. On the other hand, a scenario where part of the current fertilizer subsidies were re-directed to also support local-scale organic fertilizer production or (training in) agro-ecological soil fertility practices would compensate for the knowledge-based conversion costs.

The study indicated that the overall food production in the organic scenario would be approximately $5 \%$ lower in Tamil Nadu and 3\% lower in Madhya Pradesh given the relative yields used in the models. This 5 and $3 \%$ reduction at the state level may lead to higher food prices which may have a negative impact on the food security of the urban poor and landless rural people. However, conversion to organic has the advantages of reducing the production costs and the indebtedness, and of increasing the income, of the marginal and the small farmers who constitute $80 \%$ of the food insecure in India ${ }^{2}$. Moreover, most of the farms in Tamil Nadu were under a conversion period when the household survey was conducted ${ }^{15}$ so there is a reason to believe that the organic yields may increase in Tamil Nadu after completion of the conversion period. The estimated pulse yields were conservative, because not all the families had yet introduced pulses due to lack of knowledge and seeds. Similarly, in the Madhya Pradesh case study which forms the basis of the relative yields a private company supports specific organic crops for a lucrative export market but the organic farmers are lacking knowledge and inputs to grow the full range of rotational food crops ${ }^{15}$. These factors resulted in a relatively conservative estimate of the state-level food production in our organic scenario. As discussed in Halberg et al. ${ }^{13}$ modeling of the food security consequences of large-scale conversion to organic agriculture is mostly sensitive to the projections of relative yield growth over time, and given the current low degree of research and, training in agro-ecological farming methods, there seems to be a wide potential for significant yield improvements in the organic systems in India.

Conversion of the rainfed areas to organic agriculture was found to be potentially beneficial for smallholder farmers because of almost comparable yields under these conditions and reduced input costs. Following this rationale, 76 and $40 \%$ of the area which is rainfed in Madhya Pradesh and Tamil Nadu, respectively (Tables 1 and 2), and $55 \%$ of the total rainfed agricultural land in India ${ }^{37}$, have conditions of competitive organic yields and large numbers of smallholder farms, which makes conversion to organic agriculture potentially interesting. Other studies also reported improvement in the yield and the income in rainfed areas by adopting organic farming $^{36,38}$ and conservation tillage ${ }^{39}$. Conservation technologies such as zero or minimum tillage with direct seeding, residue cover and crop rotations, combined with better use of organic sources of nutrients including animal manure, crop residues and legumes, have potential to increase the water and nutrient use efficiency, and are also effective in reducing soil organic carbon losses ${ }^{40}$.

An additional benefit of converting to organic agriculture is that the higher pulse and legume oilseed production in the organic situation could increase the protein content in the diets of impoverished families ${ }^{16}$ and may help to counter the protein malnutrition that persists among more than $50 \%$ of the Indian population ${ }^{19}$. Such a reintroduction of more pulses in the smallholder farms is not theoretically exclusive to organic systems, but fits well into a logic of using locally available resources and agroecological practices for soil improvement and human nutrition. However, low yield in the organic system, particularly in irrigated conditions, is the major barrier for such a large-scale conversion ${ }^{41}$. Adopting organic practices with no tillage and direct seeded rice in irrigated areas has a potential to improve the water use efficiency and yield in addition to reducing the global warming potential (about 75\%) compared to the conventional puddled transplanting method of rice ${ }^{40}$. Two recent comprehensive meta-analyses compared the yields of organic and non-organic agriculture in three sets of conditions, irrigated versus rainfed, legumes versus non-legumes and developed versus developing countries, and found that organic yields were higher in rainfed areas, and in systems with legumes in developing countries ${ }^{11,12}$.

We acknowledge that this study is a short-term analysis of food production, not considering the nutrient availability, price fluctuation and variation in yields over the long run. Although conversion to organic farming has economic and environmental benefits, only a portion of small and marginal farmers is converting, with the support of the NGOs and other organic-promoting organizations. Moreover, the large portion of farmers are not converting to organic due to lack of knowledge, unavailability of technology, fear of loss of yield and low confidence in controlling pests and diseases in organic methods and lack of institutional support regarding production technology ${ }^{41}$. Hence, more research is needed to understand the long-term impact of organic conversion on food production, nutrient demand and supply, and food security in India, as a potential measure to improve 
local food security for the millions of food insecure, resource poor and indebted smallholder farmers.

\section{Conclusion}

This study indicates that conversion to organic farming may increase the gross margin of marginal and small farms by reducing their production costs and debts in an organic scenario with a policy that subsidizes fertilizer use for conventional farms. Among the two states, conventional farmers in Tamil Nadu were more affected than those in Madhya Pradesh because of their more extensive use of fertilizer and higher fertilizer subsidy per holding. The advantage of organic farming was larger under a scenario without fertilizer subsidies and the study suggests diverting part of the fertilizer subsidies to supporting organic and agro-ecological soil fertility measures. Largescale conversion of marginal and small farms can have a small negative impact on the overall state-level food production. This study showed that the rainfed areas of marginal and small farms were more suitable for conversion to organic farming in the short run, due to comparable organic and conventional yields. Thus, 76 and $40 \%$ of the rainfed area, in Madhya Pradesh and Tamil Nadu, respectively, and $55 \%$ of the rainfed areas of the country are suitable for organic agriculture. Conversion of the irrigated areas can have a negative impact on food production and food security, but an increased cultivation of pulses and oilseeds (legume oilseeds - peanut and soybean) may compensate partly for the lower cereal yields. Organic production that has a higher proportion of legumes, crop diversification and a lower cost of production can potentially alleviate the consequences of crop failure resulting in further indebtedness of poor families, which is common in Indian agriculture. Although the study addresses short-term perspectives of large-scale conversion to organic farming, more research is needed to understand the long-term impact of organic conversion on food production, nutrient demand and supply, and poverty reduction.

Acknowledgement. We thank the International Centre for Research in Organic Food System (ICROFS) for funding this research through the GlobalOrg project.

\section{References}

1 Donald, W.L., Eugene, J., Pannu, R.S., and Sheokand, R.S. 2004. Instability in Indian agriculture - a challenge to the green revolution technology. Food Policy 29:257-273.

2 FAO (Food and Agricultural Organization). 2008. The state of food insecurity in the world. Available at Web site http:// www.fao.org/docrep/011/i0291e/i0291e00.htm (accessed January 15, 2009).

3 Agricultural Census. 2001. Agricultural Census Division, Ministry of Agriculture, New Delhi. Available at Web site http://agcensus.nic.in/ (accessed July 10, 2009).
4 Scialabba, N.E. 2007. Organic agriculture and food security. In International Conference on Organic Agriculture and Food Security, May 3-5, 2007, Food and Agriculture Organization of the United Nations, Italy. (OFS/2007/5). Available at Web site http://www.fao.org/organicag (accessed December 12, 2013).

5 IFAD (International Fund for Agricultural Development). 2005. Organic Agriculture and Poverty Reduction in Asia: China and India Focus. Available at Web site http://www. ifad.org/evaluation/public $\% 5 \mathrm{Fhtml} / \mathrm{eksyst} / \mathrm{doc} /$ thematic/ organic/ (accessed April 26, 2010).

6 Marriott, E.E. and Wander, M.M. 2006. Total and labile soil organic matter in organic and conventional farming systems. Soil Science Society of America Journal 70:950-959.

7 Fließbach, A., Oberholzer, H.R., Gunst, L., and Mäder, P. 2007. Soil organic matter and biological soil quality indicators after 21 years of organic and conventional farming. Agriculture, Ecosystems and Environment 118:273-284.

8 Bengtsson, J., Ahnström, J., and Weibull, A.C. 2005. The effects of organic agriculture on biodiversity and abundance: A meta-analysis. Ecology 42:261-269.

9 Tscharntke, T., Clough, Y., Wanger, T.C., Jackson, L., Motzke, I., Perfecto, I., Vandermeer, J., and Whitbread, A. 2012. Global food security, biodiversity conservation and the future of agricultural intensification. Biological Conservation 151:53-59.

10 UNEP-UNCTAD. 2006. The Status of Organic Agriculture Production and Trading Opportunities in Tanzania. Final Report presented at the UNEP-UNCTAD Capacity Building Task Force of Trade, Environment and Development Regional Workshop on Organic Agriculture in East Africa, March 6-10, Arusha, Tanzania.

11 Seufert, V., Ramankutty, N., and Foley, J.A. 2012. Comparing the yields of organic and conventional agriculture. Nature 485:229-232.

12 De Ponti, T., Rijk, B., and Van Ittersum, M.K. 2012. The crop yield gap between organic and conventional agriculture. Agricultural Systems 108:1-9.

13 Halberg, N., Rosegrant, P., Sulser, T., Knudsen, M.T., and Høgh-Jensen, H. 2006. The impact of organic farming on food security in a regional and global perspective. In N. Halberg, M.T. Knudsen, H.F. Alrøe, and E.S. Kristensen (eds). Global Development of Organic Agriculture: Challenges and Prospects. CABI Publishing, Wallingford, UK. p. 277-322. Available at Web site http://ecowiki.org/ GlobalPerspective/ReportOutline (accessed December 12, 2013).

14 Badgley, C., Moghtader, J., Quintero, E., Zakem, E., Chappell, M.J., Avilés-Vàzques, K., Samulon, A., and Perfecto, I. 2007. Organic agriculture and the global food supply. Renewable Agriculture and Food Systems 22:86-108

15 Panneerselvam, P. 2011. Improving smallholder's food security through organic agriculture in India. $\mathrm{PhD}$ thesis, Faculty of Science and Technology, Aarhus University, Aarhus, Denmark.

16 Panneerselvam, P., Hermansen, J., and Halberg, N. 2011. Food security of small holding farmers: Comparing organic and conventional systems in India. Journal of Sustainable Agriculture 35:1-21.

17 Eyhorn, F., Ramakrishnan, M., and Mäder, P. 2007. The viability of cotton-based organic farming systems in 
India. International Journal of Agricultural Sustainability 5:25-38.

18 Ministry of Finance. 2008. Economic survey. Ministry of Finance, Government of India. Available at Web site http:// indiabudget.nic.in/es2006-07/agriculture.htm (accessed December 12, 2013).

19 Indian National Science Academy. 2009. Nutrition security for India: Issues and way forward. Available at Web site http://typo3.fao.org/fileadmin/user_upload/fsn/docs/ Symposium_Report_Nutrition_Security_India.pdf (accessed August 8, 2010).

20 Kanyama, A.C. 1998. Climate change and dietary choiceshow can emission of greenhouse gases from food consumption be reduced? Food Policy 23:77-293.

21 Ramasamy, C., Ramanathan, S., Balasubramanian, T.N., Ragupathy, N., Natarajan, S., Devasenapathy, P., and Natarajan, N. 2004. Alternative Cropping Pattern for Tamil Nadu. Directorate of Research, Tamil Nadu Agricultural University, Coimbatore.

22 Das, P. 2002. Cropping Pattern (Agricultural and Horticultural) in Different Zones, their Average Yields in Comparison to National Average/Critical Gaps/Reasons Identified and Yield potential. Indian Council of Agricultural Research, New Delhi. Available at Web site http://agricoop. nic.in/Farm\%20Mech.\%20PDF/05024-02.pdf (accessed June 10, 2003).

23 Kar, G., Singh, R., and Verma, H.N. 2004. Alternative cropping strategies for assured and efficient crop production in upland rainfed rice areas of eastern India based on rainfall analysis. Agricultural Water Management 67(1):47-62.

24 Ministry of Agriculture. 2009. Agricultural statistics at a glance. Directorate of Economics and Statistics, Ministry of Agriculture, Government of India. Available at Web site http://eands.dacnet.nic.in/At_Glance_2009.htm (accessed December 12, 2013).

25 Statistical Handbook. 2010. Department of Economics and Statistics, Government of Tamil Nadu. Available at Web site http://www.tn.gov.in/deptst/Stat.htm (accessed April 26, 2010).

26 NSS (National Sample Survey). 2007. Household Consumer Expenditure among Socio-Economic Groups: 2004-2005. National Sample Survey 61st Round. Report No. 514(61/1.0/7). Ministry of Statistics and Program Implementation, Government of India.

27 Hanson, J.C., Lichtenberg, E., and Peters, S.E. 1997. Organic versus conventional grain production in the MidAtlantic: An economic and farming system overview. American Journal of Alternative Agriculture 12:2-9.

28 Setboonsarng, S., Stefan, A., Leung, P.S., and Cai, J. 2008. Profitability of organic agriculture in a transition economy: the case of organic contract rice farming in Lao PDR. Paper presented at Cultivating the Future Based on Science: 2nd Conference of ISOFAR, Modena, Italy, June 18-20, 2008.

29 Schumacher, P. 2004. Comparison of conventional and biological cotton production in India, Maikaal area: Cropping pattern, production costs and farmer income.
Diploma thesis, Department of Geography, University of Zurich, Zurich.

30 Rasul, G. and Thapa, G.B. 2004. Sustainability of ecological and conventional agricultural systems in Bangladesh: An assessment based on environmental, economic and social perspectives. Agricultural Systems 79:327-351.

31 Rajeev, M., Vani, B.P., and Bhattacharjee, M. 2011. Nature and Dimensions of Farmer's Indebtedness in India and Karnataka. The Institute for Social and Economic Change, Bangalore, working paper 267.

32 Araya, H. and Edwards, S. 2006. The tigray experience: A success story in sustainable agriculture. Third World Network Environment and Development series 4. TWN: Penang, pp 45. In: Vaarst M. 2010. Organic farming as a development strategy: Who are interested and who are not? Journal Sustainable Development 3:38-50.

33 Sharma, V.P. and Thaker, H. 2009. Fertilizer Subsidy in India: Who are the Beneficiaries? Indian Institute of Management, Ahmedabad, India. WP No. 2009-07-01. Available at Web site http://www.indiaenvironmentportal. org.in/files/fertilizer\%20subsidy.pdf (accessed July 10, 2010).

34 Dimitri, C., Kemp, L., Sooby, J., and Sullivan, E. 2012. Organic farming for health and prosperity. Organic Farming Research Foundations. Available at Web site http:/l www.ofrf.org/sites/ofrf.org/files/docs/pdf/HP-report-web.pdf (accessed April 10, 2013).

35 Carating, R., Fernando, M., Abrina, Y., and Tejada, C. 2011. The Organic Fertilizer Production Project: Community-Based and Small Scale Soil Fertility and Farm Waste Management Strategies in Support of the National Rice and Corn Program. Bureau of Soils and Water Management, Elliptical Road, Diliman, Quezon City, Philipines.

36 Purushothaman, S., Patil, S., and Francis, L. 2012. Impact of policies favoring organic inputs on small farms in Karnataka, India: A multicriteria approach. Environment Development Sustainability 14:507-527.

37 Ministry of Agriculture. 2011. Agricultural statistics at a glance. Directorate of Economics and Statistics, Ministry of Agriculture, Government of India. Available at Web site http://eands.dacnet.nic.in/latest_20011.htm (accessed March 15, 2013).

38 Letter, D., Seidel, R., and Liebhardt, W. 2003. The performance of organic and conventional cropping systems in an extreme climate year. American Journal of Alternative Agriculture 18:146-154.

39 Ghosh, P.K., Das, A., Saha, R., Kharkrang, E., Tripathi, A.K., Munda, G.C., and Ngachan, S.V. 2010. Conservation agriculture towards achieving food security in North East India. Current Science 99:915-921.

40 Bhatia, A., Kumar, A., Kumar, V., and Jain, N. 2013. Low carbon technologies for sustainable agriculture. Indian Farming 63(2):18-22.

41 Panneerselvam, P., Halberg, N., Vaarst, M., and Hermansen, J.E. 2011. Indian farmers experience with and perception of organic farming. Renewable Agriculture and Food Systems 27:157-169. 